Mitsubishi Tanabe, Nippon Kayaku, Novartis, Pfizer Japan Inc, Taiho, Taisho Toyama, Takeda, Teijin, Grant/research support from: Astellas Pharma Inc., Bristol Myers Squibb, Chugai Pharmaceutical Co., Ltd., Mitsubishi Tanabe Pharma Co., Pfizer Japan Inc., Santen Pharmaceutical Co., Ltd., Takeda Pharmaceutical Co., Ltd., Teijin Pharma Ltd., AbbVie GK, Asahi Kasei Pharma Corp., Taisho Toyama Pharmaceutical Co., Ltd., SymBio Pharmaceuticals Ltd., Janssen Pharmaceutical K.K., Celltrion Inc., Nipponkayaku Co. Ltd., and UCB Japan, Consultant for: Astra Zeneca K. K., Eli Lilly Japan K.K., Novartis Pharma K.K., Mitsubishi Tanabe Pharma Co., Abbivie GK, Nipponkayaku Co.Ltd, Janssen Pharmaceutical K.K. Astellas Pharma Inc., Taiho Pharmaceutical Co. Ltd., Chugai Pharmaceutical Co. Ltd., Taisho Toyama Pharmaceutical Co. Ltd., GlaxoSmithKline K. K., UCB Japan Co. Ltd., Consultant for: AbbVie, Asahi Kasei, Astellas, AstraZeneca, AYUMI, Bristol-Myers Squibb, Chugai, Daiichi Sankyo, Eisai, Eli Lilly Japan, Janssen, Mitsubishi Tanabe, Nippon Kayaku, Novartis, Pfizer Japan Inc, Taiho, Taisho Toyama, Takeda, Teijin, Consultant for: Astra Zeneca K.K., Eli Lilly Japan K.K., Novartis Pharma K.K., Mitsubishi Tanabe Pharma Co., Asahi Kasei Medical K.K., AbbVie GK, Daiichi Sankyo Co., Ltd., Bristol Myers Squibb, and Nipponkayaku Co. Ltd., Speak ers bureau: Astellas Pharma Inc., Bristol Myers Squibb, Chugai Pharmaceutical Co., Ltd., Mitsubishi Tanabe Pharma Co., Pfizer Japan Inc., Santen Pharmaceutical Co., Ltd., Takeda Pharmaceutical Co., Ltd. Teijin Pharma Ltd., AbbVie GK, Asahi Kasei Pharma Corp., Taisho Toyama Pharmaceutical Co., Ltd., SymBio Pharmaceuticals Ltd., Janssen Pharmaceutical K.K., Celltrion Inc., Nipponkayaku Co. Ltd., and UCB Japan, Speakers bureau: AbbVie, Asahi Kasei, Astellas, AstraZeneca, AYUMI, Bristol-Myers Squibb, Chugai, Daiichi Sankyo, Eisai, Eli Lilly Japan, Janssen, Mitsubishi Tanabe, Nippon Kayaku, Novartis, Pfizer Japan Inc, Taiho, Taisho Toyama, Takeda, Teijin, Speakers bureau: AbbVie GK., Bristol-Myers K.K., Chugai Pharmaceutical Co. Ltd., Mitsubishi Tanabe Pharma Co., Pfizer Japan Inc., Astellas Pharma Inc, Diaichi Sankyo Co. Ltd., Eisai Co. Ltd., Sanofi K.K., Teijin Pharma Ltd., Takeda Pharmaceutical Co. Ltd., Novartis Pharma K.K., Hisashi Yamanaka Grant/ research support from: AbbVie, Eisai, Bristol-Meyers, Novartis, Behringer, Astellas, Kaken, Nippon-Shinyaku, Pfizer, UCB, Ayumi, Ono, Daiichi-Sankyo, Taisyo-Toyama, Takeda, Tanabe-Mitsubishi, Chugai, Teijin Pharma, Torii, YLbio, Speakers bureau: Bristol-Meyers, Astellas, Pfizer, Daiichi-Sankyo, Takeda, Tanabe-Mitsubishi, Chugai, Teijin Pharma, YLbio, Toshihiro Nanki Grant/research support from: Chugai, Eisai, Takeda, Teijin, Eli Lilly, Bristol-Myers, AbbVie, Ono, Novartis, Asahikasei, Mitsubishi-Tanabe, Astellas, Ayumi, Pfizer, Daiichi Sankyo, Shionogi, Sanofi, Nippon Kayaku, Yutoku, Actelion, UCB, Bayer, Nihon Pharmaceutical., Consultant for: UCB, Eisai, Chugai, Ono, Gilead., Speakers bureau: Mitsubishi-Tanabe, Chugai, Eisai, Takeda, Astellas, Janssen, Eli Lilly, Ayumi, Pfizer, Asahikasei, Sanofi, Daiichi Sankyo, Otsuka, AbbVie, Ono, Teijin, Nippon Kayaku, UCB., Hisanori Umehara: None declared, Nobuyuki Yasuda Shareholder of: Eisai Co., Ltd., Employee of: KAN Research Institute, Inc. (subsidiary of Eisai Co., Ltd.), Fumitoshi Tago Employee of: Eisai Co., Ltd., Yasumi Kitahara Shareholder of: Eisai Co., Ltd., Employee of: Eisai Co., Ltd., Makoto Kawakubo Shareholder of: Eisai Co., Ltd., Employee of: Eisai Co., Ltd., Hayato Hisaki Shareholder of: Eisai Co., Ltd., Employee of: Eisai Co., Ltd., Seiichiro Hojo Employee of: Eisai Co., Ltd., Tetsu Kawano Employee of: KAN Research Institute, Inc. (subsidiary of Eisai Co., Ltd.), Toshio Imai Shareholder of: Eisai Co., Ltd., Employee of: KAN Research Institute, Inc. (subsidiary of Eisai Co., Ltd.)

DOI: 10.1136/annrheumdis-2019-eular.1894

\section{SAT0127 LONG-TERM OUTCOME OF CHILDREN BORN TO MOTHERS WITH CHRONIC ARTHRITIS AND EXPOSED TO TNF-INHIBITORS DURING PREGNANCY: A CASE- CONTROL STUDY}

Maria Chiara Gerardi ${ }^{1}$, Laura Andreoli ${ }^{1}$, Chiara Bazzani ${ }^{1}$, Matteo Filippini ${ }^{2}$ Micaela Fredi ${ }^{1}$, Roberto Gorla ${ }^{2}$, Maria Grazia Lazzaroni ${ }^{1}$, Cecilia Nalli ${ }^{2}$, Marco Taglietti ${ }^{2}$, Andrea Lojacono ${ }^{3}$, Sonia Zatti ${ }^{3}$, Mario Motta ${ }^{4}$, Angela Tincani ${ }^{1}$. ${ }^{1}$ Rheumatology and Clinical Immunology, Spedali Civili and University of Brescia, Brescia, Italy, Brescia, Italy, ${ }^{2}$ Rheumatology and Clinical Immunology, Spedali Civili, Brescia, Italy, Brescia, Italy, ${ }^{3}$ Obstetrics and Gynaecology, Spedali Civili and University of Brescia, Brescia, Italy, Brescia, Italy; ${ }^{4}$ Neonatology and NICU, Spedali Civili, Brescia, Italy, Brescia, Italy

Background: Treatment with tumor necrosis factors inhibitors (TNFi) during pregnancy may be required in order to control maternal disease which itself can be a threat for maternal-fetal well-being and pregnancy outcome. Information about the follow-up of in utero exposed offspring is limited Objectives: The aim of this study was to compare the health and developmental conditions of children born to mothers with chronic arthritis who were exposed in utero to TNFi with those of unexposed children born to patients with the same age at conception and disease.

Methods: An ad-hoc created questionnaire was used to collect data on birth and growth parameters, breastfeeding, weaning, developmental milestones, vaccinations and illnesses.

Results: 122 live births in 97 women with chronic arthritis (65 RA and $32 \mathrm{SpA}$ ) were observed: 59 pregnancies were exposed to TNFi at the time of conception and 63 pregnancies were TNFi-naïve. In 57/59 (97\%) pregnancies, TNFi was discontinued at positive pregnancy index. In 2/59 (3\%) pregnancies TNFi was mantained throughout pregnancy due to active disease at conception. TNFi was restarted in 16/57 pregnancies (28\%) (10 ETA, $5 \mathrm{CTZ}, 1 \mathrm{ADA})$ during the $2^{\text {nd }}-3^{\text {rd }}$ trimester due to mod erate-severe flare (median exposure 22 weeks; discontinuation of TNFi between 32-39 gestational weeks). In second group, TNFi (1 ETA, 1 CTZ) was introduced in $2 / 63(3 \%)$ pregnancies during the $2^{\text {nd }}$ trimester due to a severe flare. 16 in $16 / 63$ (25\%) pregnancies were managed with an increase of prednisone ( $\max 10 \mathrm{mg} / \mathrm{day}$ ). To investigate the longterm follow-up of children exposed in utero to TNFi, 61 children exposed to $\mathrm{TNFi}$ at conception or during $2^{\text {nd }}-3^{\text {rd }}$ trimester (median age 29 months) and 61 unexposed children (median age 49 months) were compared. No significant differences in growth parameters and developmental milestones were observed. No excess nor particular pattern of congenital defects $/ \mathrm{mal}$ formations were observed. In both groups, vaccinations were performed according to the national schedule (no live vaccines in the first year of life) without relevant complications (Figure 1).

Conclusion: TNFi may be required in patients that experienced flare during pregnancy and they are effective in controlling maternal disease and ensures a good pregnancy outcome without complications for the health and growth of exposed children.

\begin{tabular}{|c|c|c|c|c|c|}
\hline & \multicolumn{2}{|c|}{ Pregnancies exposed to TNFi $(n=61)$} & \multirow{2}{*}{$\begin{array}{c}P \\
\text { valu } \\
e\end{array}$} & \multirow{2}{*}{$\begin{array}{c}\text { Pregnancies } \\
\text { unoxposod to } \\
\text { TNFi } \\
(n=61)\end{array}$} & \multirow{2}{*}{$\begin{array}{r}P \\
\text { valu }\end{array}$} \\
\hline & $\begin{array}{c}\text { TNFi until } \\
\text { positive pregnancy } \\
\text { index }(n=41)\end{array}$ & $\begin{array}{c}\text { TNFi during } \\
\text { the } \\
2^{n-6}-3^{\prime \triangleleft} \text { trimester } \\
(n=20)\end{array}$ & & & \\
\hline 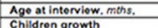 & $32(10-86)$ & $20(7.153)$ & & $42(7.169)$ & \\
\hline 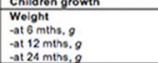 & 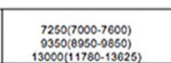 & 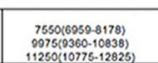 & $\begin{array}{l}0.05 \\
0.09 \\
0.16\end{array}$ & 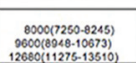 & $\begin{array}{l}0.01 \\
0.01 \\
0.08\end{array}$ \\
\hline 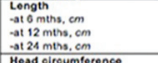 & $\begin{array}{l}07(05-08) \\
7(574.77)\end{array}$ & 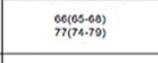 & $\begin{array}{l}0.05 \\
0.20\end{array}$ & 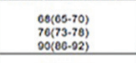 & $\begin{array}{l}0.06 \\
0.18 \\
0.16\end{array}$ \\
\hline 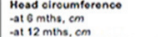 & $\begin{array}{l}43(42-24) \\
46(45-47)\end{array}$ & $\begin{array}{l}44(42-14) \\
47(45 \cdot 40)\end{array}$ & 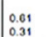 & 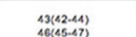 & $\begin{array}{l}0.46 \\
0.06\end{array}$ \\
\hline 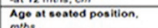 & $6(6.7)$ & 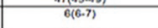 & 0.41 & 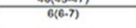 & 0,38 \\
\hline 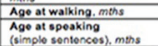 & $\frac{12(11 \cdot 13)}{20(15-24)}$ & $\frac{13(11 \cdot 16)}{19(12 \cdot 24)}$ & $\begin{array}{l}\frac{0.17}{0.77} \\
\end{array}$ & $\frac{13(11-14)}{26(14-24)}$ & $\frac{0.32}{0.52}$ \\
\hline 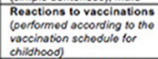 & 1 rash post measios vaccines & 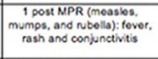 & & 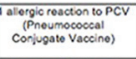 & \\
\hline $\begin{array}{l}\text { Pathologicalcal condition } \\
\text { during the first yost of ito }\end{array}$ & 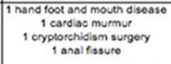 & 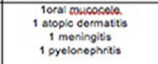 & & 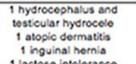 & \\
\hline Pathologicas conditione & 1 autsm spostrum Gitorser & 1ambyopias & & 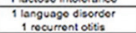 & \\
\hline
\end{tabular}

Acknowledgement: None

Disclosure of Interests: Maria Chiara Gerardi: None declared, Laura Andreoli: None declared, Chiara Bazzani: None declared, Matteo Filippini: None declared, Micaela Fredi: None declared, Roberto Gorla: None declared, Maria Grazia Lazzaroni: None declared, Cecilia Nalli: None declared, Marco Taglietti: None declared, Andrea Lojacono: None declared, Sonia Zatti: None declared, Mario Motta: None declared, Angela Tincani Consultant for: UCB, Pfizer, Abbvie, BMS, Sanofi, Roche, GSK AlphaSigma, Lilly, Jannsen, Cellgene, Novartis DOI: 10.1136/annrheumdis-2019-eular.3076

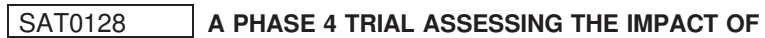 RESIDUAL INFLAMMATION AND CLINICAL CHARACTERISTICS ON THE OUTCOME OF DOSE TAPERING OF ADALIMUMAB IN PATIENTS WITH RHEUMATOID ARTHRITIS WHO ARE IN STABLE CLINICAL REMISSION}

Paul Emery ${ }^{1}$, Gerd Rüdiger Burmester ${ }^{2}$, Esperanza Naredo ${ }^{3}$, Ivan LagunesGalindo ${ }^{4}$, Franziska Koenigsbauer ${ }^{5}$, Philip G. Conaghan ${ }^{1} .{ }^{1}$ University of Leeds and NIHR Leeds Biomedical Research Centre, Leeds, United Kingdom; ${ }^{2}$ Charité Universitätsmedizin, Berlin, Germany, ${ }^{3}$ Hospital Universitario Fundación Jiménez Díaz, Madrid, Spain; ${ }^{4}$ AbbVie, Inc., North Chicago, United States of America; ${ }^{5}$ AbbVie Deutschland GmbH and Co. KG, Ludwigshafen, Germany

Background: For rheumatoid arthritis (RA) pts in stable clinical remission (SCR) on bDMARDs, EULAR and ACR recommend to consider tapering 